\title{
JARANAN POGOGAN TEGUH RAHAYU DESA SUGIHWARAS, PRAMBON, KABUPATEN NGANJUK (KAJIAN HOLISTIK)
}

\author{
Marinda Lisa Anggraini \\ Institut Seni Indonesia (ISI) Surakarta \\ Jalan Ki Hadjar Dewantara No. 19 Kentingan, Jebres, Surakarta 57126 \\ Sutarno Haryono \\ Institut Seni Indonesia (ISI) Surakarta
}

\begin{abstract}
Abstrak
Penelitian ini bertujuan untuk mendiskripsikan dan mengkaji secara anilitis tentang Jaranan Pogogan Teguh Rahayu. Metode penelitian yang digunakan adalah metode penelitian kualitatif dengan menggunakan pendekatan kritik seni holistik. Tahap penelitian yang digunakan adalah pengumpulan data dengan melakukan observasi, wawancara, dan studi pustaka. Seluruh data yang didapat kemudian di analisis dengan menggunakan pendekatan kritik holistik yang mencakup faktor genetik, faktor objektif serta faktor afektif. Hasil temuan bahwa Kesenian Jaranan Pogogan Teguh Rahayu merupakan kesenian yang diciptakan selain sebagai sarana hiburan juga sebagai sarana edukasi. Terdapat pesan-pesan moral dibalik setiap penyajiannya seperti semangat juang, kerja keras dan perintah-perintah untuk melakukan kebaikan.
\end{abstract}

Kata kunci: Jaranan Pogogan Teguh Rahayu, Kritik Seni Holistik.

\section{Abstract}

The goal of this research is to describe and carry out an analytical study of Jaranan Pogogan Teguh Rahayu. A qualitative research method is used with a holistic art criticism approach. The stages of the research include data collection through observation, interviews, and a library study. All the data obtained is then analyzed using a holistic art criticism approach which includes the genetic factors, objective factors, and affective factors. The research results show that the art of Jaranan Pogogan Teguh Rahayu was created as a form of entertainment and also as a medium for education. Every performance contains moral messages, such as the need for a fighting spirit, the importance of hard work, and instructions to perform good deeds.

Keywords: Jaranan Pogogan Teguh Rahayu, Holistic Art Criticism.

\section{PENDAHULUAN}

Kesenian Jaranan merupakan salah satu kesenian yang masih berkembang di pulau Jawa, khususnya di Jawa Timur.
Beberapa macam kesenian Jaranan yang terdapat di Jawa timur, seperti Jaranan Senterewe, Jaranan Dor, Jaranan Pegon, Jaranan Pogogan dan masih banyak lagi. 
Kesenian Jaranan di wilayah Kabupaten Nganjuk mulai dikenal masyarakat luas. Akibatnya, muncul beberapa kesenian Jaranan yang serupa tapi memiliki ciri khas yang berbeda. Kesenian Jaranan di Nganjuk pada awalnya diperkenalkan oleh seseorang yang berasal Desa Judel yang bertempat di bawah kaki Gunung Wilis yang berbatasan dengan Kabupaten Ponorogo dan Kabupaten Kediri.

Pada tahun 1956 berdiri suatu paguyuban Jaranan Pogogan Teguh Rahayu yang berada di Desa Sugihwaras Kecamatan Prambon Kabupaten Nganjuk di bawah pimpinan Eko Kadiyono. Jaranan Pogogan yang ada di Desa Sugihwaras Kecamatan Prambon Kabupaten Nganjuk diberi nama Teguh Rahayu dengan maksud kesenian ini bisa tetap hidup sampai kapanpun seiring dengan kemajuan jaman dan tidak mudah hilang digerus oleh kesenian yang meninggalkan seni tradisi. Jaranan Pogogan Teguh Rahayu, lahir dan hidup di tengahtengah masyarakat pedesaan, sehingga kesenian ini dapat dikatakan sebagai kesenian rakyat guna untuk memenuhi atau menjawab kebutuhan rohani masyarakat.

Seni pertunjukan rakyat adalah juga sebagai seni tradisional, merupakan proses kreativitas masyarakat untuk menjawab kebutuhan rohani masyarakat. Bentuk seni pertunjukan rakyat yang sering juga disebut seni rakyat relatif beragam setiap daerah, tumbuh dan berkembang dalam lingkungan pedesaan, didukung oleh kelompok masyarakat secara turuntemurun (Soemaryatmi, 2015:37).

Pada dasarnya kesenian Jaranan Pogogan di Desa Sugihwaras Kecamatan Prambon Kabupaten Nganjuk ini mengangkat siklus panji. Para seniman
Pogogan ini mengemas dan memberi variasi terhadap Jaranan Pogogan dengan sedemikian rupa yang mempunyai maksud supaya dapat menarik perhatian penikmatnya. Seperti pendapat Gendhon Humardani dalam Rustopo bahwa.

Seni rakyat didukung oleh kelompok masyarakat yang homogen yang menunjukkan sifat-sifat solidaritas yang nyata, dalam hal ini adalah masyarakat pedesaan atau pedalaman. Bentuknya tunggal tidak beragam, tidak halus dan tidak rumit. Penguasaan terhadap bentuk-bentuk semacam itu dapat dicapai dengan tidak melalui latihan-latihan khusus. Peralatannya sederhana dan terbatas. Dalam penyajiannya juga seolah-olah tidak ada batas antara pemain dan penonton. Situasi seperti ini menyebabkan seni rakyat sangat akrab dengan lingkungannya (2001:106-107).

Peneliti memilih pendekatan menggunakan kritik seni holistik karena dianggap mampu bagi peneliti untuk dapat membahas tentang Jaranan Pogogan Teguh Rahayu Desa Sugihwaras Kecamatan Prambon Kabupaten Nganjuk secara lebih lengkap dan lebih fokus untuk menjelaskan tentang latar belakang Jaranan Pogogan Teguh Rahayu, Bentuk Jaranan Pogogan Teguh Rahayu, respon masyarakat terhadap pertunjukan kesenian Jaranan Pogogan Teguh Rahayu, serta integrasi hubungan antara komponen non-verbal dan verbal yang terdapat pada Jaranan Pogogan Teguh Rahayu sehingga menghasilkan makna yang dapat ditarik dari integrasi antara hubungan non-verbal dan verbalyang terdapat pada Jaranan Pogogan Teguh Rahayu.

Pendekatan kritik seni holistik dalam Jaranan Pogogan Teguh Rahayu dianggap 
mampu untuk membahas hubungan antara latar belakang seniman dan keseniannya (Faktor Genetik), Jaranan Pogogan Teguh Rahayu (Faktor Objektif), respon masyarakat (Faktor Afektif), dan makna yang terbentuk sebagai hasil dari hubungan ketiga komponen tersebut.

\section{JARANAN POGOGAN TEGUH RAHAYU DESA SUGIHWARAS}

Kesenian rakyat merupakan suatu kesenian yang lahir dan berkembang di tengah masyarakat. Suatu kesenian yang lahir dan berkembang di tengah-tengah masyarakat memiliki bentuk yang berbedabeda atau memiliki ciri khas tertentu. Kesenian Jaranan Pogogan awalnya diperkenalkan oleh Kasmani (Alm) yang berasal dari Desa Judel yaitu sebuah desa yang terletak di kaki Gunung Wilis, tepatnya di perbatasan antara Kabupaten Ponorogo dan Kabupaten Kediri. Pada tahun 1952 Kasmani mulai mengamen dengan memperkenalkan kesenian jathilan di Desa Betet Kecamatan Ngronggot Kabupaten Nganjuk yang memiliki keunikan berupa jathilan bergaya seperti wayang orang.

Pada tahun yang sama, Ragil salah satu masyarakat Dusun Barik tertarik untuk mendirikan paguyuban Jaranan dimana para pemainnya merupakan pemuda yang dilatih oleh Kasmani. Dari situlah kesenian Jaranan bergaya wayang orang yang diberi sentuhan gecul yang dikenal dengan Jaranan Barik mulai mengalami masa kejayaan. Jaranan Barik merupakan sebutan awal sebelum adanya sebutan Jaranan Pogogan, hal itu karena masyarakat sekitar menganggap bahwa Jaranan tersebut berasal dari Dusun Barik.
Empat tahun setelah kejayaan Jaranan Barik, tepatnya tahun 1956 lahirlah Jaranan Pogogan Teguh Rahayu di Desa Sugih waras Kecamatan Prambon Kabupaten Nganjuk yang di prakarsai oleh Maridjo yang memiliki bentuk yang hampir sama dengan Jaranan Bariknamun berbeda dengan Jaranan ndadi yang ada di Kabupaten Nganjuk. Bentuk pada suatu kesenian merupakan hal pokok yang dimiliki oleh suatu kesenian itu sendiri termasuk tari. Bentuk adalah perpaduan dari beberapa unsur atau komponen yang bersifat fisik, saling mengkait dan terintegrasi dalam suatu kesatuan (Maryono, 2015:24). Berdasarkan pendapat Maryono, dapat dilihat pada Jaranan Pogogan Teguh Rahayu dalam bentuk sajiannya memiliki suatu bentuk fisik yang hampir sama dengan Jaranan Barik namun berbeda dengan Jaranan ndadi yang ada di Jawa Timur, misalnya pada Jaranan Pogogan Teguh Rahayu dan Jaranan Barik terdapat dialog dalam sajiannya, sehingga penari berhenti sesaat dengan sebuah sikap atau pose yang terkesan ndagel atau lucu dalam setiap sajiannya. Setiap adegannya memiliki hubungan yang saling berkaitan satu sama lain.

Dalam suatu kesenian tidak dapat terlepas dari tiga faktor utamanya yaitu Seniman (Faktor Genetik), Keseniannya itu sendiri (Faktor Objektif) dan Penghayat (Faktor Afektif). Dalam membahas tentang bentuk Jaranan Pogogan Teguh Rahayu secara lebih lengkap, peneliti akan menjelaskan lebih rinci mulai dari Faktor Genetik (Seniman), Faktor Objektif (komponen verbal dan komponen nonverbal) Jaranan Pogogan 
Teguh Rahayu dan Faktor Afektif yaitu tanggapan yang diberikan oleh para masyarakat yang mengapresiasi Jaranan Pogogan Teguh Rahayu.

\section{a. Faktor Genetik Jaranan Pogogan Teguh Rahayu.}

Lahirnya suatu kesenian tidak bisa dipungkiri bahwa, pada saat diciptakan seniman mempunyai maksud dan tujuan tertentu dalam menciptakan kesenian itu sendiri. Pembahasan tentang hal-hal kemunculan Jaranan Pogogan Teguh Rahayu ini menggunakan kritik seni holistik. Jaranan Pogogan Teguh Rahayu merupakan kesenian rakyat yang tidak bisa lepas dengan seniman dan konsep-konsep pembentukan keseniannya (faktor genetik). Sesuai dengan pendapat H.B Sutopo bahwa latar belakang (faktor genetik) yang berupa segala hal yang berkaitan dan terjadi sebelum karya, konteks awalnya, sebelum program terwujud, dan juga proses pembentukannya (2006:144). Kedudukan faktor genetik dalam seni menjadi jelas seperti yang dinyatakan oleh Rochana dan Pramutomo sebagai berikut.

Komponen genetik merupakan banyak hal yang meliputi kepribadian seniman, kondisi psikologisnya, selera, ketrampilan, kemampuan, pengalaman, latar belakang sosial budaya, dan berbagai peristiwa di sekitarnya. Semuanya merupakan berbagai hal di belakang karya (Rochana dan Pramutomo, 2007:36).

Konseppenyusunan atau berdirinya Jaranan Pogogan Teguh Rahayu meliputi: pemilihan jenis cerita, dan proses pembentukan Jaranan Pogogan Teguh Rahayu. Pemilihan jenis cerita pada Jaranan Pogogan ini diambil dari kisah seorang
Senopati yang diiringi oleh seorang Tumenggung yang suka melucu dan dua prajurit wanita yang telah melakukan perjalanan panjang dengan menunggang kuda. Cerita ini sebenarnya diangkat dari siklus panjimyaitu prajurit-prajurit yang ditugaskan oleh Lembu Amiluhur untuk mencari jejak hilangnya putri mahkota Dewi Sekartaji. Di tengah-tengah perjalanan sang Tumenggung (Pogog) sering berhenti dan melucu, dan berdialog antara Pogog, Sasra, prajurit wanita, kemudian diperintahkan untuk menggerak-gerakan bagian-bagian tubuhnya itu. Gerakan-gerakan itu semakin lucu karena hentakan-hentakan atau gerakan-gerakan tubuh yang sering berlebihan dimanfaatkan oleh gerak sang Pogog.

Pada tahun 1956 Kesenian Jaranan Pogogan Teguh Rahayu pertama kali muncul di Desa Sugihwaras Kecamatan Prambon, tepatnya di Dusun Jimbir yang diprakarsai oleh Maridjo. Maridjo adalah salah satu seniman yang mempunyai peran penting dalam paguyuban Jaranan Pogogan Teguh Rahayu dan berasal dari Dusun Jimbir Desa Sugihwaras. Awalnya Maridjo dalam merintis dan mendirikan paguyuban Jaranan Pogogan Teguh Rahayu menginginkan adanya suatu kesenian yang berbentuk jaranan khas di desanya, maka Maridjo berpikir untuk mendirikan suatu kesenian dimana di dalamnya mengemas kesenian seperti Jaranan, Tayub, Ludruk dan Wayang menjadi satu di dalamnya.

Keinginan Maridjo dan kondisi pada saat itu didukung dengan kondisi dimana laki-laki lebih dominan daripada perempuan di Dusun Jimbir, maka Maridjo berpikir untuk mendirikan satu kesenian yang di dalamnya mengemas semua kesenian seperti Jaranan, 
Tayub, Ludruk dan Wayang ke dalam Jaranan Pogogan yang diberi nama Teguh Rahayu dengan maksud kesenian tersebut tetap awet tidak gampang digerus oleh waktu. Pogogan sendiri adalah nama irah-irahan yang dikenakan oleh salah seorang tokoh, kemudian tokoh tersebut dikenal dengan sebutan Pogog. Pemberian nama kesenian ini hanya mengambil nama salah satu tokoh yaitu Pogog, karena tokoh Pogog sangat menonjol dan dominan pada kesenian tersebut, Seperti yang diungkapkan Maridjo bahwa Maridjo ingin menggarap Jaranan Pogogan Teguh Rahayu ke dalam lima adegan yaitu genjongan, pogogan, kucingan, klanan dan ringgit tiyang (Eko Kadiyono, wawancara 3 Oktober 2017).

Awal mula adanya adegan genjongan, Maridjo menginginkan pada setiap pertunjukannya terdapat adegan pembuka, adegan isi dan adegan penutup. Demi merealisasikan adegan pembuka tersebut, Maridjo memberikan adegan genjongan di awal sajian sebagai tarian penyambutan. Adegan yang kedua merupakan adegan Pogogan. Penggarapan konsep Pogogan diambil dari cerita panji yang mengisahkan tentang seorang senopati diiringi oleh seorang tumenggung yang suka melucu dan dua prajurit wanita yang telah melakukan perjalanan panjang dengan menunggang kuda.

Adegan ketiga merupakan adegan kucingan. Konsep penggarapan pada adegan kucingan berbeda dengan barongan atau kucingan pada jaranan ndadi yang ada di Jawa Timur. Adegan ke empat merupakan adegan Klanan. Penggarapan Klanan pada Jaranan Pogogan Teguh Rahayu menampilkan sisi jenaka dari tokoh Klana. Adegan ke lima merupakan adegan Ringgit Tiyang.
Penggarapan adegan Ringgit Tiyang awal mulanya karena pada saat pertama masuknya kesenian Jaranan Pogogan di Kabupaten Nganjuk merupakan Jaranan yang hanya menggunakan kostum dan bergaya wayang wong, maka pada sajian selanjutnya digarap dengan sedemikian rupa oleh para seniman Pogogan dan ceritanyajuga sudah berkembang dengan mengambil lakon dari cerita rakyat maupun cerita yang diambil dari epos Mahabarata dan Ramayana.

Pogogan disini memiliki arti ndagel, tugel atau tidak utuh dengan maksud dalam sajiannya tidak selalu menari namun diselingi dengan dialog-dialog lucu oleh para penarinya. Banyaknya laki-laki pada saat itu, membuat Maridjo berpikir untuk menambah kesan ndagel maka untuk beberapa penari ada yang ditarikan oleh laki-laki yang berdandan seperti wanita cantik dan satu tokoh penting dengan riasan menyerupai punakawan sebagai tokoh yang dominan dalam kesenian Jaranan Pogogan yang disebut pogog. Ada juga alasan lain mengapa para penari yang menari adalah laki-laki yang berdandan seperti wanita, karena pada jaman dahulu terlalu banyak resiko apabila mengajak perempuan untuk tanggapan atau pentas pada malam hari saat itu (Eko Kadiyono, wawancara 2 Februari 2018).

\section{b. Faktor Objektif Jaranan Pogogan Teguh Rahayu}

Tari merupakan bagian dari kebudayaan yang diekspresikan dalam bentuk seni pertunjukan. Dalam pertunjukan tari terdapat satu sifat komunikasi dari pencipta untuk menyampaikan pesan kepada penghayat melalui karya tarinya. Kehadirannya bukan hanya sekedar sebagai sarana hiburan, namun juga membawa 
makna yang terkandung di dalamnya yang berupa nilai moral maupun spiritual.

Faktor utama objektif terdiri atas teks nonverbal dan teks verbal. Komponen verbal sebagai media untuk menyampaikan maksud secara efektif dan efisien sehingga dapat diketahui secara nalar, jelas, dan tidak terjadi interpretasi lain. Komponen non verbal merupakan medium bantu yang dapat menekankan maksud tertentu sehingga mudah tersampaikan dengan jelas, menarik dan mantap (Haryono, 2010:170).

Pendapat dari Sutarno Haryonodapat diaplikasikan untuk membahas faktor objektif yang terdiri dari komponen non-verbal dan verbal yang terdapat pada Jaranan Pogogan Teguh Rahayu. Sajian tentang komponen non-verbal dan verbal pada Jaranan Pogogan Teguh Rahayu diuraikan sebagai berikut.

\section{Komponen Non-Verbal Jaranan Pogogan.}

Komponennon-verbal merupakan salah satu komponen yang terdapat pada faktor objektif. Komponen non-verbal terdiri atas gerak tari, karawitan tari, desain waktu, rias busana, properti dan cahaya.

Komponen non-verbal yang terdapat pada Jaranan Pogogan Teguh Rahayu Desa Sugihwaras Kecamatan Prambon Kabupaten Nganjuk tersebut akan dijelaskan lebih rinci sebagai berikut.

\section{a. Gerak Tari}

Dalam setiap pertunjukan tari, gerak merupakan medium dasar yang harus diperhatikan. Melalui gerak, seorang penari dapat menyampaikan pesan yang ingin koreografer sampaikan kepada penonton.
Konsep garapan gerak tari dapat menjelaskan pijakan gerak yang dipakai dalam koreografi, misalnya dari tradisi klasik atau tradisi kerakyatan, modern dance, atau kreasi penemuan bentuk-bentuk gerak alami, studi gerak-gerak binatang, studi gerak dari kegiatan-kegiatan lain seperti jenis olah tubuh atau olah raga, serta berbagai macam pijakan yang dikembangkan secara pribadi (Murgiyanto, 2003:86).

Secara kuantitatif menunjukkan bahwa gerak representtif lebih dominan dibandingkan dengan gerak presentatif. Jumlah presentase gerak presentatif maupun gerak representatif yang terdapat pada Jaranan Pogogan Teguh Rahayu didapatkan dari jumlah vokabuler gerak. Gerak representatif yang terdapat pada Jaranan Pogogan Teguh Rahayu seperti mlaku-mlaku, ngglebak, menthul-menthul, jalan ditempat, lilingan, obah dhada tancep dipadukan dengan adu suri kuda, kiprahan, isen-isen, mlaku mubeng tancep adalah menggambarkan prajurit yang sedang melakukan perjalanan dan berlatih ilmu kanuragan.

Gerak representatif yang terdapat pada Jaranan Pogogan Teguh Rahayu mencapai $76,19 \%$ adalah untuk menggambarkan semangat jiwa seseorang dalam menjalani perjalanan kehidupan dan berlatih ilmu kanuragan. Adanya gerak presentatif pada Jaranan Pogogan Teguh Rahayu yang mencapai $23,80 \%$ menunjukan bahwa pada kesenian ini masih menggunakan gerak murni dimana mengutamakan keindahan dan untuk pemenuhan kebutuhan ekspresi.

\section{b. Pola Lantai}

Pada sajian pertunjukan juga terdapat berbagai macam bentuk pola lantai. Seperti pendapat Maryono mengenai pola lantai 
yaitu pola lantai merupakan garis yang dibentuk dari gerak tubuh penari pada lantai atau panggung pertunjukan merupakan garis imajiner yang dapat ditangkap dengan kepekaan rasa (2015:58). Sependapat dengan Maryono, Jaranan Pogogan Teguh Rahayu dalam pementasannya juga terdapat gari imajiner yang dapat ditangkap dengan kepekaan rasa. Berikut penjelasan mengenai pola lantai pada sajian Jaranan Pogogan Teguh Rahayu. a). Pola Lantai Adegan Genjongan.

Adegan Genjongan terdapat dua pola lantai. Pola lantai yang digunakan adalah melingkar dan berbaris membentuk formasi dua dua satu. Pada adegan Pogogan terdapat beberapa pola lantai seperti baris, berjajar ke belakang, melingkar, dan berhadapan. Pola lantai baris digunakan pada saat penari kuda perempuan memasuki tempat pementasan, pada pola lantai baris sekaran yang digunakan adalah mlaku-mlaku, kemudian pola lantai berjajar ke belakang digunakan pada saat empat penari kuda keluar, gerakan yang dilakukan adalah obah dhadha, obah dhadha tancep, dan wangsalan, disusul dengan pola lantai melingkar sebagai penghubung gerak biasanya terdapat pada sekaran mlakumlaku mubeng tancep yang terakhir adalah pola lantai berhadapan digunakan pada saat kiprahan ke empat penari dengan menggunakan sekaran wiwiran sampur, adu suri kuda, tempelan kanan, tempelan kiri, dan ukel pakis.

Pada adegan Kucingan pola lantai yang dipakai pada gerakan seperti meloncat, lilingan, embat tangan, langit bumi, jengkengan, ngadek ngilo, geolan dan hormat masuk. Gerakan-gerakan tersebut tidak mempunyai urutan yang pakem tetapi merupakan gerakan atau sekaran yang pasti pada Kucingan. Pola lantai yang digunakan adalah berjajar dan berhadapan.

Pada adegan Klanan mempunyai bentuk pola lantai yang acak, karena pada adegan ini hanya ditarikan oleh satu orang sebagai Klana, sedangkan satu orang yang menabuh kepyak hanya duduk di tengah dan tidak ikut menari. Pola lantai penari Klanan biasanya hanya memutari penabuh kepyak.

Pola lantai pada adegan Ringgit Tiyang tidak menentu, namun ada beberapa pola lantai yang digunakan seperti berhadapan, dan adu bahu kiri. pemilihan pola lantai tersebut sering digunakan juga pada cerita-cerita atau pethilan cerita lain yang digunakan dalam adegan Ringgit Tiyang. Berikut merupakan gambar pola lantai yang sering digunakan pada adegan Ringgit Tiyang pethilan Bambangan Cakil.

\section{c. Penari}

Dalam suatu sajian tari, penari merupakan objek yang menjadi fokus perhatian bagi para penonton. Penari merupakan media bagi koreografer untuk menyampaikan maksud atau sesuatu dari koreografer kepada penonton. Penari pada Jaranan Pogogan Teguh Rahayu dominan lakilaki. Pemilihan penari laki-laki itu awalnya dipengaruhi oleh keadaan lingkungan dimana penduduknya dominan laki-laki dan pada zaman dahulu jika mengajak penari wanita terdapat banyak resikonya. Para penari yang terdapat pada paguyuban Jaranan Pogogan Teguh Rahayu memang memiliki beberapa pertimbangan untuk pemilihannya. Adapun penari pada Jaranan Pogogan Teguh Rahayu akan dijelaskan sebagai berikut.

Penari Genjongan atau yang dikenal dengan istilah Gambyong pada sajian yang 
ditampilkan oleh paguyuban Jaranan Pogogan Teguh Rahayu memilih para penarinya adalah laki-laki yang berdandan seperti wanita.

Pemilihan penari laki-laki ini awalnya karena keadaan masyarakat yang berdominan laki-laki dan pada awal munculnya Jaranan Pogogan dahulu memang apabila mengajak penari perempuan itu mempunyai banyak resiko. Ditambah lagi dengan tujuan utamanya yang ingin menonjolkan gecul maka para penari laki-laki tersebut berdandan seperti layaknya perempuan. Jumlah penari pada adegan Genjongan ada empat penari. Jumlah empat pada penari Genjongan menyimbolkan papat kiblat menurut orang jawa. (Eko Kadiyono, wawancara 2 Februari 2018)

Penari pada adegan Pogogan ada empat penari laki-laki yang memiliki peran masing-masing. Peran para penari meliputi tokoh Sasra, Pogog, dan dua sebagai penari kuda putri. Tokoh Sasra ditarikan oleh penari laki-laki yang berpenampilan atau berdandan alusan seperti tokoh Janaka dengan karakter alusan. Satu penari berdandan sebagai tokoh Pogog. Tokoh Pogog adalah tokoh yang dominan dalam sajian Jaranan Pogogan. Pemain Pogog tidak bisa sembarang pemain, karena tokoh Pogog

harus mampu mengerti kendangan, gending dan juga pandai melawak. Penari kuda putri ditarikan oleh dua penari laki-laki yang berdandan seperti wanita. Para penari ini merupakan penari seperti berpasangan antara Sasra dengan penari kuda putri yang satu dan Pogog berpasangan dengan penari kuda putri yang lainnya.

Penari pada adegan Kucingan ada dua orang. Pembagian penarinya yaitu satu orang sebagai penari Kucingan dan yang satu adalah sebagai penari pawang. Penari Kucingan ditarikan oleh satu penari laki-laki dengan menggunakan topeng kucing dengan gerak-gerak akrobatik seperti melompat dan bergulung. Tokoh pawang ditarikan oleh lakilaki yang berdandan seperti wanita. Pemilihan penari pada adegan ini sebenarnya mengambil penari dari adegan Genjongan yang dirasa mampu untuk merangkap sebagai tokoh pawang karena pada dasarnya seperti yang sudah dijelaskan bahwa para penari Jaranan Pogogan harus bisa merangkap peran pada setiap adegannya.

Penari Klanan ditarikan oleh satu penari laki-laki yang memiliki tubuh bidang. Dalam adegan ini juga terdapat satu orang laki-laki penabuh kepyak, tetapi tidak ikut menari hanya duduk dan memukul kepyak. Pada adegan Klanan pemainnya juga harus pandai untuk melawak.

Pada sajian ini tidak menampilkan tokoh Klanan seperti yang ada pada Reog Ponorogo, namun seniman Pogogan mengemasnya dalam suatu bentuk adegan kesenian yang berbeda dimana tetap menampilkan penampilan yang tidak jauh dari adegan geculan dengan memberikan sentuhan dialog dan tembang.

Ringgit tiyang dalam pementasannya tidak menentu pemilihan judul dan lakonnya. Dalam memainkan perannya, para penari Pogogan biasanya bergantian dalam setiap judulnya. Penari pada Ringgit Tiyang pada intinya juga para penari yang menari dari adegan-adegan sebelumnya, namun hanya berganti busana saja. Pemilihan penarinya dipilih oleh dalang. Pada Ringgit Tiyang biasanya jika membutuhkan peran atau tokoh perempuan, para seniman mengatasi dengan mengambil penari laki-laki yang berhias atau berdandan seperti wanita. Hal 
tersebut dilakukan semata hanya untuk menambah kesan gecul dan mendapat pengaruh dari kesenian ludruk dimana pada zaman dahulu pemainnya ada laki-laki yang berdandan seperti wanita. Cerita yang dibawakan biasanya juga disanggit oleh para seniman Pogogan dengan menambah adegan-adegan geculan.

\section{d. Rias dan Busana}

Pada sebuah pertunjukan tari salah satu unsur terpenting adalah rias dan busana. Rias dan busana yang digunakan oleh seorang penari dapat mewakili karakter yang dibawakan oleh penari itu sendiri. Adegan Genjongan menggunakan rias cantik seperti halnya riasan yang digunakan pada penari Gambyong. Rias cantik yang digunakan pada adegan Genjongan berfungsi untuk menampilkan sisi cantik seorang wanita pada penari Genjongan. Meskipun para penari adalah laki-laki yang berdandan wanita, namun dalam geraknya tidak kalah luwes dan kenes dari penari wanita. Busana yang digunakan penari Genjongan hampir sama dengan kostum Gambyong yang ada di Jawa Tengah namun tidak menggunakan kemben atau angkin tetapi menggunakan kebaya. Penggunaan kostum yang dipilih untuk adegan Genjongan ini bertujuan agar terlihat indah, karena adanya pengaruh ludruk pada tahun 1980. Keindahan pada kostum dilihat dari apabila para penari pria yang berdandan seperti wanita memakai kebaya dapat terlihat seperti wanita yang sebenarnya yang terlihat cantik, sopan, luwes dan lugu.

Pada adegan Pogogan terdapat empat penari dengan rias dan busana yang berbeda. Tokoh Pogog riasan yang digunakan adalah rias korektif dengan mengutamakan kesan gecul. Adapun bahan dan alat rias yang digunakan adalah pembersih wajah, bedak dasar, bedak padat, lipstik dan yang singwit. Riasan korektif yang digunakan oleh tokoh pogog dimaksudkan untuk mengutamakan kesan gecul dapat menarik perhatian para penonton. Selain rias yang digunakan oleh Pogog, juga terdapat busana yang digunakan antara lain rompi yaitu baju yang tidak berlengan biasanya berwarna merah bisa juga hitam, celana panjen atau bisa juga menggunakan celana hitam yang dihiasi dengan pinggiran merah yaitu celana yang panjangnya setinggi lutut bagian bawah yang ujungnya dihias dengan pita.

Penari kuda putri merupakan salah satu bagian dari penari yang terdapat pada adegan Pogogan. Terdapat rias dan busana yang digunakan oleh penari kuda putri. Riasannya adalah rias cantik, hampir sama seperti rias yang digunakan pada penari yang terdapat pada adegan Genjongan yang cenderung lebih tipis. Penggunaan rias cantik pada adegan Pogogan adalah sebagai pelengkap agar para penari pria dapat terlihat cantik layaknya penari wanita. Selain rias cantik yang digunakan, juga terdapat busana yang digunakan pada penari putri yang terdapat pada adegan Pogogan. Pada awalnya penari putri kuda menggunakan irah-irahan beserta sumping (seperti tokoh wayang wong Srikandhi dan Larasati) akan tetapi pada perkembangan selanjutnya dengan keterbatasan busana dan adanya pengaruh dari busana kesenian ludruk, maka yang dikenakan penari putri pada Jaranan Pogogan antara lain seperti sanggul,

Sasra merupakan salah satu tokoh yang berdandan seperti Janaka atau Bambangan. Pada Jaranan Pogogan Teguh Rahayu tokoh Sasra ini disajikan untuk menggambarkan seorang prajurit yang 
tangguh namun tidak meninggalkan kesan gecul atau lucunya. Rias yang digunakan adalah rias alusan. Bahan rias yang digunakan antara lain pembersih wajah, alas bedak, bedak tabur atau bedak padat, blush on atau pemerah pipi, pensil alis berwarna hitam, lipstick atau pewarna bibir yang berwarna merah.

Kucingan dalam sajian Jaranan Pogogan Teguh Rahayu memang berbeda dengan Kucingan yang ada pada Jaranan Sentherewe. Ada dua tokoh yaitu pawang dan Kucingan itu sendiri dengan rias dan busana yang berbeda. Pada tokoh Kucingan tidak menggunakan riasan wajah karena dalam menari menggunakan topeng Kucingan atau yang sering disebut dengan barongan. Pada tokoh pawang riasan yang digunakan adalah rias cantik dengan bahan riasan yang digunakan adalah pembersih dan penyegar wajah, alas bedak, bedak tabur atau bedak padat, pensil alis, eye shadow, blush on dan lipstick berwarna merah. Busana yang digunakan untuk Kucingan adalah celana berumbai merah dan kuning juga memakai stagen, tidak menggunakan baju karena tertutup dengan kemul Kucingan yang digunakan.

Klanan pada sajian Jaranan Pogogan Teguh Rahayu masih menyajikan kesankesan gecul. Rias dan busana yang digunakan juga berbeda dengan klanan yang berada pada sajian Reog Ponorogo. Pada adegan Klanan, terdapat tokoh Klanan dan penabuh kepyak. Rias yang digunakan adalah rias natural, karena pada saat penyajiannya tokoh Klanan menggunakan topeng, meskipun sering sekali membuka topeng pada saat berdialog, sedangkan penabuh kepyak tidak menggunakan riasan atau hanya sekedar menggunakan bedak tipis. Busana yang digunakan pada tokoh Klanan yaitu kaos berwarna merah dan putih, celana panji berwarna hitam, stagen, boro samir berwarna hitam dan emas, kaos kaki warna merah panjang, sepatu bola, uncal, epek timang dan jarik.

Adegan Ringgit Tiyang merupakan adegan yang berubah-ubah lakon dan jalan ceritanya setiap pementasan. Hal itu dikarenakan atas permintaan yang mempunyai hajat. Dalam pementasannya, adegan Ringgit Tiyang pernah memainkan atau mementaskan pethilan cerita Bambangan Cakil. Terdapat rias dan busana pada adegan ini. Tokoh Janaka menggunakan rias alusan. Penggunaan rias dan busana alusan untuk menampilkan tokoh Bambangan dalam adegan Ringgit Tiyang, sedangkan tokoh Cakil menggunakan rias karakter cakil untuk menampilkan karakter cakil pada sajiannya.

\section{e. Properti}

Properti adalah benda pendukung sajian pada sebuah pertunjukan tari. Penggunaan properti akan dapat dikatakan mendukung apabila properti tersebut mengandung makna dalam suatu sajian tari.

Rahayu menggunakan properti seperti kuda kepang yang digunakan pada adegan kepangan atau Pogogan. Pada adegan Klanan juga menggunakan properti berupa topeng klana berwarna merah. Topeng Klanan yang digunakan terbuat dari kayu yang diukir dan dipahat menyerupai bentuk wajah dengan mata yang besar, hidung menjulang dan kelihatan giginya. Warna merah pada Klanan memberikan kesan tegas dan tangkas. Berikut merupakan contoh topeng yang digunakan pada adegan Klanan Jaranan Pogogan Teguh Rahayu Desa Sugihwaras Kecamatan Prambon Kabupaten Nganjuk. 


\section{f. Desain Waktu}

Dalam suatu pertunjukan tari dapat diamati dari rangkaian-rangkaian ragam geraknya terdapat tempo, ritme yang berbeda-beda. Dalam setiap pertunjukan tari terdapat durasi yang berlangsung.

Durasi dipahami sebagai jangka waktu berapa lama gerakan itu berlangsung. Barangkali dalam hitungan detik atau menit, bahkan dapat lebih panjang lagi sebuah gerakan itu dilakukan (Hadi, 2003:51)

Biasanya pertunjukan Jaranan Pogogan Teguh Rahayu dipentaskan atas permintaan yang punya hajat seperti pernikahan, khitanan, peringatan bersih desa atau nyadran, juga pada peringatan 17 Agustus dan ada juga dipentaskan untuk sarana pembayar nadzar atau ngluari ujar. Pementasan Jaranan Pogogan Teguh Rahayu biasanya dilakukan pada siang ataupun malam hari. Durasi pementasannya pada saat awal kemunculan Jaranan Pogogan apabila disajikan secara keseluruhan mulai dari adegan Genjongan, Pogogan, Kucingan, Klanan dan Ringgit Tiyang maka pementasan yang dilakukan pada saat malam hari dimulai pada pukul $21.00 \mathrm{Wib}$ dan selesai pada pukul 03.00 Wib dini hari, namun sekarang pementasannya karena adanya aturan dari pihak keamanan maka hanya dilakukan pementasan dimulai pada pukul 19.00 Wib dan selesai paling malam pukul $24.00 \mathrm{Wib}$.

\section{g. Cahaya}

Cahaya adalah penerangan yang dibutuhkan pada setiap pertunjukan tari. Sumber cahaya yang digunakan untuk suatu pementasan pertunjukan tari adalah lampu. Ada beberapa lampu yang digunakan yaitu seperti lampu general, dan lampu yang memiliki banyak warna. Pada Jaranan Pogogan Teguh Rahayu menggunakan cahaya untuk mendukung pertunjukannya. Cahaya ini mempunyai fungsi untuk mempertegas bentuk wajah karakter dan ekspresi wajah penari.

Seperti halnya rias dan kostum, peranan tata cahaya stage lighting sangat mendukung suatu bentuk pertunjukan tari...lighting menggunakan general light bersifat penerangan sepenuhnya kurang lebih 100\% karena tema garapan ini menggambarkan keceriaan, senang, kemegahan, suasana hingar binar, dan sebagainya (Hadi,2003:92).

Pendapat Sumandiyo Hadi dapat diaplikasikan pada Jaranan Pogogan Teguh Rahayu. Dalam pementasannya, jika dipentaskan pada malam hari menggunakan lampu general. Pemakaian lampu general mempunyai fungsi untuk dapat mempertegas riasan wajah, bentuk karakter serta ekspresi wajah yang dikeluarkan oleh pemain diatas panggung, selain itu juga karena kesan pertunjukan yang mempunyai banyak bagian yang gecul maka pemilihan lampu general dianggap paling terbaik. Pementasan jika dilakukan pada siang hari menggunakan cahaya dari sinar matahari.

\section{h. Musik Tari}

Suatu sajian tari tidak terlepas dari musik tari. Musik tari memiliki fungsi sebagai efek suara dan memberikan kelengkapan pada suatu sajian tari. Musik tari adalah nyawa sebuah tarian, karena karawitan selain sebagai pengiring juga dapat mewujudkan suasana yang dikehendaki oleh penari dalam pertunjukkan. 
Dalam pertunjukan tari khususnya, tari dan musik merupakan suatu perkawinan yang harmonis. Jangan sekali-kali beranggapan bahwa musik sebagai abdi tari, tetapi sebaliknya musik jangan sampai mendominir tari. Dalam pertunjukan tari musik harus betul-betul sebagai pengiring yaitu "mengiringi" tari (Hadi, 2003:56).

Dalam penyajiannya, Jaranan Pogogan Teguh Rahayu diiringi dengan musik tari yang mendominan. Pertunjukkan Jaranan Pogogan ini antara penabuh dengan penari sering mengadakan komunikasi, gerak mengikuti iringan atau sebaliknya. Para penabuhnya laki-laki sesuai dengan jumlah alatnya. Biasanya tembang dilantunkan oleh pemain Pogog. Adapun instrumen yang digunakan antara lain kendhang gedhe, thimplung, kenong, gong, slompret, dan kepyak pada Jaranan Pogogan Teguh Rahayu.

\section{Komponen Verbal Jaranan Pogogan Teguh Rahayu}

Seluruh objek yang bersifat kebahasaan dalam suatu pertunjukan tari merupakan komponen verbal. Adapun macam bahasa verbal yang terdapat pada Jaranan Pogogan Teguh Rahayu adalah adaada, tembangan, pocapan, dan dialog. Membahas tentang kebahasaan dalam pertunjukan tari, maka digunakan pendapat tentang tindak tutur oleh Kreidler dalam buku Sutarno Haryono yaitu bahwa tindak tutur dapat diklarifikasikan menjadi tujuh jenis tindak tutur, diantaranya : assertive, performative, verdictive, expressive, directive, commissive, dan phatic" (2010: 20-24). Tujuh jenis tindak tutur pendapat Kreidler digunakan untuk membahas tindak tutur yang terdapat pada ada-ada, tembangan, janturan, dan dialog yang terdapat pada
Jaranan Pogogan Teguh Rahayu. Komponen verbal yang terdapat pada adegan Genjongan adalah berupa tembang pada saat sekaran tayuban. Tembangan yang disajikan merupakan jenis dari tembang pangkur (Caraka Wuri Utama, 27 April 2018).

Adapun jenis tindak tutur yang paling banyak adalah tindak tutur asertif. Tembang yang terdapat pada adegan Genjongan menunjukkan suatu pesan atau pernyataan bahwa wanita yang sempurna baik dari fisik maupun tindak tanduknya. Dilihat secara garis besar tembang yang ada pada adegan Genjongan menggambarkan seorang wanita yang berkepribadian baik dan menarik yang diwujudkan dengan para penari Genjongan yang berdandan bagaikan wanita cantik yang luwes dalam membawakan tariannya. Berdasarkan lagu dan sekaran yang dibawakan oleh para penari terdapat keserasian secara musikal sehingga suasananya hanya terkesan rame dan dinamis.

Pada adegan Pogogan terdapat beberapa macam komponen verbal dalam sajiannya seperti ada-ada, pocapan, tembangan serta beberapa dialog yang memberikan kesan gecul atau lucu dalam pementasannya. Pada dialog, biasanya membahas tentang halhal yang terkadang juga terjadi dalam kehidupan sehari-hari, seperti celotehancelotehan yang keluar secara sepontan dari mulut, bergurau, pitutur, juga kritikankritikan terhadap politik dan sebagainya yang dikemas dalam dialog kehidupan sehari-hari yang menarik. Biasanya dialog ini untuk selingan di tengah- tengah adegan Pogogan.

Adapun jenis tindak tutur yang paling banyak adalah tindak tutur Direktif. ada-ada, pocapan, maupun dialog yang terdapat pada 
adegan pogogan berdominan adalah sebuah perintah, dimana perintah yang baik yaitu untuk melestarikan budaya tanpa adanya pamrih atau imbal balik dengan diselingi beberapa dialog lucu sebagai hiburan. Berdasarkan pada ada-ada, pocapan dan dialog yang dibawakan pemain pada adegan Pogogan terdapat keserasian sehingga gerakannya terkesan sigrak dan harmoni. Pada adegan Klanan juga terdapat komponen verbal berupa dialog anatar tokoh Klana dan penabuh kepyak. Dialog yang digunakan menggunakan bahasa sehari-hari. Hal-hal yang dibahas biasanya mengenai fenomenafenomena yang terjadi di kehidupan seharihari dan secara spontan.

Adapun jenis tindak tutur yang paling banyak adalah tindak tutur Direktif. Dialog yang berisikan tentang dialog-dialog yang berisi perintah, permintaan dan usulan. Dibalik tutur kata yang terlontar dari kedua tokoh memiliki maksud yang tersirat bahwa dalam bekerja harusnya giat, jika tidak tahu atau tidak mengerti harus bertanya mau bagaimanapun keadaannya jika kondisi fisik masih mumpuni harus tetap giat dalam bekerja. Hal itu juga terlihat pada gerak yang dilakukan oleh tokoh Klanan yaitu gerakgerak yang sigrak sehingga terlihat sangat harmonis.

Pada adegan Ringgit Tiyang terdapat komponen verbal dalam sajiannya seperti $a d a-$ ada dan dialog. Pada sajian ringgit tiyang yang mengangkat pethilan cerita Bambangan Cakil menggunakan dialog yang biasanya terdapat pada sajian wayang wong. Pada dialognya tersirat kesan keangkuhan dan ketidak sabaran seseorang pada kehidupan sehari-hari yang terlihat dari dialog Cakil, dan kesan wibawa yang terlihat dari dialog Bambangan.
Adapun jenis tindak tutur yang paling banyak adalah tindak tutur direktif. Dialog yang berisikan tentang perintah, permintaan dan usulan yaitu seperti menyuruh menyebutkan siapa sebenarnya Bambangan oleh Cakil. Dibalik tutur kata yang terlontar dari kedua tokoh memiliki maksud yang tersirat bahwa dalam bersosialisasi harus memiliki sopan santun dalam meminta sesuatu dan tidak melontarkan kata-kata sombong yang dapat mengakibatkan pertikaian. Hal itu juga terlihat pada gerak setelah dialog selesai yaitu perang yang dilakukan oleh tokoh Bambangan dan Cakil.

\section{c. Faktor Afektif Jaranan Pogogan Teguh Rahayu Desa Sugihwaras Kecamatan Prambon Kabupaten Nganjuk}

Dalam suatu kesenian ada beberapa persoalan pokok yang terdapat didalamnya. Seperti yang diungkapkan oleh Nooryan sebagai berikut.

Ada tiga persoalan pokok dalam filsafat seni, yaitu benda seni (karya seni) sebagai hasil proses kreasi seniman, pencipta seni (seniman), dan penikmat seni (publik seni). Berdasarkan benda seni (karya seni) akan muncul persoalan kausal, sebagai hasil proses pemahaman dari publik atau apresiator terhadap seni, yaitu berupa nilai-nilai seni (2008:162).

Masyarakat sebagai penonton seni pertunjukan dapat dibedakan menjadi dua kelompok yaitu penonton awam dan penonton terlatih (Haryono, 2010:236). Adapun beberapa pendapat yang dikemukakan baik dari para masyarakat awam, dan masyarakat terlatih seperti pengamat seni serta para pemain Jaranan Pogogan Teguh Rahayu sendiri mengenai Jaranan Pogogan Teguh Rahayu Desa 
Sugihwaras Kecamatan Prambon Kabupaten Nganjuk.

Para penghayat baik masyarakat awam maupun masyarakat terlatih merupakan hasil dari pengamatan yang dilakukan oleh masyarakat di lapangan. Pendapat yang diungkapkan oleh masyarakat awam semata-mata hanya mereka dapat dari apa yang mereka lihat tanpa harus berfikir bagaimana kesenian tersebut dahulunya dapat berdiri dan hal lain sebagainya. Adapun pendapat yang dikatakan oleh masyarakat terlatih merupakan beberapa pendapat yang didapat bukan semata-mata hanya melihat dan dapat berpendapat, namun para masyarakat terlatih juga mendapatkan informasi baik dari perintis atau pendiri pertama Jaranan Pogogan Teguh Rahayu maupun dari referensireferensi seperti buku, dan bukti sejarah yang berkaitan dengan awal mula berdirinya Jaranan Pogogan Teguh Rahayu Desa Sugihwaras Kecamatan Prambon kabupaten Nganjuk.

\section{PENUTUP}

Berdasarkan analisis dari komponen verbal dan non-verbal pada Jaranan Pogogan Teguh Rahayu merupakan jenis tarian jaranan yang berkolaborasi dengan kesenian wayang wong atau ringgit tiyang. Kolaborasi antara wayang wong dengan kesenian jaranan tersebut digarap dalam bentuk kesenian jaranan pogogan yang diambil dari nama irah-irahan salah satu pemainnya yang tugel, serta difungsikan untuk memberikan kritikan ataupun pesan moral semangat juang dan pantang menyerah dalam menghadapi kehidupan sehari-hari kepada masyarakat dalam bentuk sebuah hiburan kesenian.
Makna dari Jaranan Pogogan Teguh Rahayu adalah mengajarkan betapa pentingnya memiliki semangat juang untuk meraih sesuatu dalam kegiatan sehari-hari, seperti mencari pekerjaan untuk memenuhi kebutuhan hidup maka harus berjuang maupun berkelana mencari pekerjaan dan apabila masih belum didapat apa yang diinginkan dilarang menyerah dan harus terus berjuang. Adanya semangat dan tekat yang kuat merupakan modal dasar yang harus dimiliki oleh setiap individu untuk dapat memotivasi diri meraih sesuatu yang diinginkan.

Adanya teks yang berupa ada-ada maupun pocapan pada awal pertunjukan dimaksudkan untuk penambah atau pendukung suasana dalam pementasan yang mempunyai tujuan agar masyarakat yang melihat kesenian Jaranan Pogogan dapat menyatu pada rasa semangat juang yang dibawakan oleh para pemain atau penarinya. Dari hal-hal seperti itu, dapat menggugah hati masyarakat sehingga masyarakat desa Sugihwaras khususnya merasa bangga mempunyai kesenian yang menjadikan identitas bagi wilayahnya, memiliki makna yang tersirat dalam setiap sajiannya, mempunyai kesenian yang memiliki pesan moral yang terkandung di dalamnya dan dapat disampaikan melalui pertunjukan yang dinilai masyarakat sangat menghibur.

Adanya adegan ringgit tiyang pada akhir sajian mencerminkan bahwa terdapat lakon dalam menjalani kehidupan sehari-hari yang berbeda-beda, maka hal itu disimbolkan dengan berbagai cerita drama yang disajikan pada akhir pertunjukan dimana cerita tersebut menceritakan tentang kehidupan yang diambil dari berbagai sumber seperti 
mitos, cerita rakyat maupun legenda yang ada di nusantara serta dengan lakon cerita yang berbeda pula.

\section{DAFTAR PUSTAKA}

Bahari, Nooryan.

2008.Kritik Seni Wacana, Apresiasi dan Kreasi.

Yogyakarta. Pustaka Pelajar.

Hadi, Y Sumandiyo.

2003."Aspek-Aspek Dasar Koreografi Kelompok."Yogyakarta. elKAPHI.

Maryono.

2015. Analisa Tari. Surakarta. ISI Press Maryono.

2011 Penelitian Kualitatif Seni Pertunjukan. Surakarta. ISI Press.

Murgiyanto, Sal.

1993 Ketika Cahaya Merah Memudar. Jakarta.Deviri Ganan.

Humardani.

2001 Gendhon Humardani: Sang Gladiator, Editor: Rustopo.Yogyakarta: Yayasan Mahavhira.

Soemaryatmi dan Suharji.

2015 Sosiologi Seni Pertunjukan

Pedesaan. Surakarta.ISI Press.
Sri Rochana dan R.M Pramutomo.

2003 Penulisan Kritik Tari. Solo. ISI Press.

Sutarno Haryono.

2010 Kajian Pragmatik Seni Pertunjukan Opera Jawa. Surakarta. ISI Press.

\section{NARASUMBER}

Eko Kadiyono (57 tahun), pemimpin atau ketua paguyuban Jaranan Pogogan Teguh Rahayu. Dusun Jimbir, Kecamatan Prambon, Kabupaten Nganjuk.

Supriyanto (51 tahun), Kepala Dinas Pariwisata Kabupaten Nganjuk, Jatikalen, Kabupaten Nganjuk

Poerwandi (71 tahun), Seniman dalang wayang pada Jaranan Pogogan Teguh Rahayu. Dusun Jimbir, Kecamatan Prambon, Kabupaten Nganjuk.

Sumiran (58 tahun), seniman dan pemusik pada Jaranan Pogogan Teguh Rahayu. Dusun Jimbir, Kecamatan Prambon, Kabupaten Nganjuk. 